\title{
First record of the non-indigenous bryozoan Amathia verticillata (delle Chiaje, 1822) (Bryozoa, Vesiculariidae) in the southern Mexican Pacific
}

\author{
Karla J. Humara-Gil ${ }^{1}$, Christopher Cruz-Gómez² \\ 1 Laboratorio de Sistemática de Invertebrados Marinos, Universidad del Mar, campus Puerto Ángel, Ciudad Universitaria, Puerto Ángel, Oaxaca, \\ 70902, México. 2 Posgrado en Ciencias en Recursos Naturales y Desarrollo Rural, El Colegio de la Frontera Sur, Unidad Chetumal, Chetumal, \\ Quintana Roo, 77014, México. \\ Corresponding author: Karla J. Humara-Gil, k.humaragil@gmail.com
}

\begin{abstract}
The non-indigenous bryozoan Amathia verticillata (delle Chiaje, 1822) is recorded for the first time from the southern Mexican Pacific. The species was detected between 2014 and 2018 at three locations along the coast of Oaxaca, southwestern Mexico: Puerto Ángel Bay, Santa Cruz Bay, and La Blanca Island. A discussion on the introduction of the species to Oaxaca is also included.
\end{abstract}

\section{Keywords}

Dispersal, exotic species, fouling, Gymnolaemata, Mexico.

\section{Introduction}

Amathia verticillata (delle Chiaje, 1822) is a marine ctenostome bryozoan (i.e. with a membranous body, enclosed by a chitinous or gelatinous cuticle), mainly known for its invasive capacity as a fouling member and its broad geographic distribution (Minchin 2012, McCann et al. 2015). This species is usually recognized by its morphological characters; the most commonly stated characters are its arborescent appearance, the clustered arrangement of the zooids on both sides of the stolon, and its trifurcated branching pattern (e.g. Winston 1995, Vieira et al. 2014, Waeschenbach et al. 2015).

The use of the name combination Amathia verticillata is quite recent. This species was first named Hydra verticillata by delle Chiaje $(1822,1828)$. Subsequently,
Ehrenberg (1831) described the genus Zoobotryon and a new species, Zoobotryon pellucidus. Soule (in Osburn 1953) transferred $H$. verticillata to Zoobotryon, naming it Zoobotryon verticillatum, and synonymized Z. pellucidus with the latter. Recently, Waeschenbach et al. (2015), based on molecular evidence, concluded that the genus Zoobotryon, as well as Bowerbankia, was a junior synonym of Amathia and proposed A. verticillata as a new combination.

Amathia verticillata is commonly found in fouling communities (Cohen and Carlton 1995, Winston 1995, Amat and Tempera 2009, Vieira et al. 2014). In the regions where the species is already established (e.g. Indian River Lagoon, Florida), it has an important role in filtering and recirculating water and also serves as a shelter for other organisms (Winston 1995). On the 


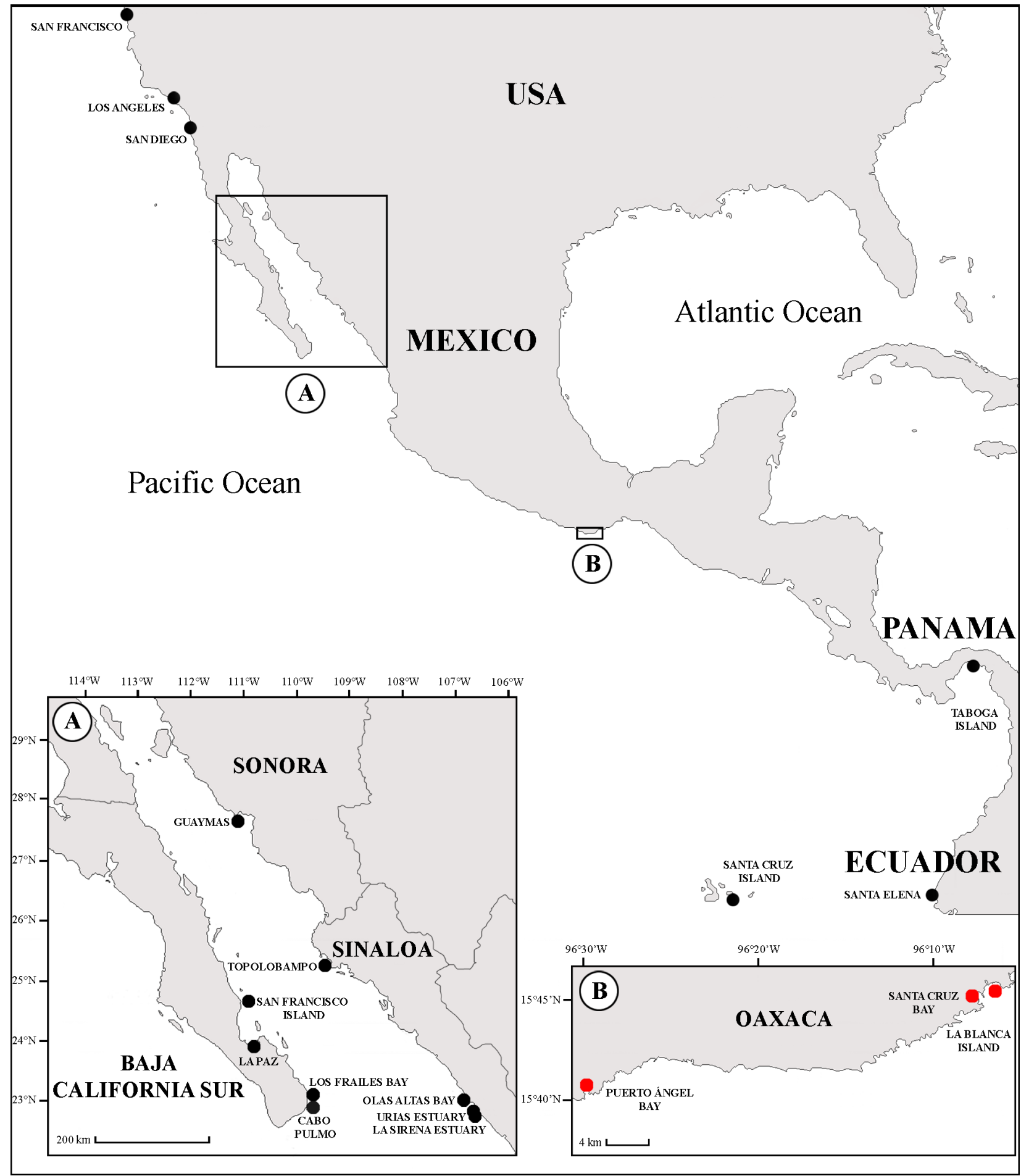

Figure 1. Distribution of Amathia verticillata in the Eastern Pacific. A, B. Records of the species in Mexico: north and south-western, respectively. Black dots indicate earlier records of the species; red dots indicate the new records included in this study.

other hand, its introduction to new areas can have negative ecological and economic impacts, including spread of smaller non-indigenous species, modifications of the trophic dynamics, collapse of local communities, and infrastructure and fishing gear damage, among others (Williams 2007, Amat and Tempera 2009, Marchini et al. 2015, McCann et al. 2015).

This bryozoan has been recorded since about 1800 from multiple locations within 35 tropical and subtropical countries and 8 islands in the Atlantic, Pacific, and Indian oceans (Winston 1995, Ferrario et al. 2014, Marchini et al. 2015, Nascimento 2015, Harmelin et al. 2016, Minchin et al. 2016, Jebakumar et al. 2017). It is because of its multiple records around the world that $A$. verticillata is acknowledged as a warm-water cosmopolitan species (Galil and Gevili 2014, Vieira et al. 2014). However, the dispersal of this species continues regardless of its already comprehensive distribution (McCann et al. 2015).

In the Eastern Pacific (EP), A. verticillata has been 
recorded from 4 countries: USA, Panama, Ecuador and Mexico (Fig. 1). The first record of the species in the EP was made by Robertson (1921), who reported its occurrence in San Diego Bay, California (USA) in the summer of 1905. Since then, multiple records (73) of A. verticillata have been made in California, from San Francisco south to San Diego (Fofonoff et al. 2018).

The species was also recorded in Central America, from Panama. A. verticillata was collected in Taboga Island in 1914, although the record was not published until the study by McCann et al. (2015) (Fig. 1).

The southernmost records of $A$. verticillata in the Pacific coast of America are from Ecuador. In this country, the species was detected in Santa Elena in 2014; since then, it has been recorded from Tortuga Bay and Franklin's Bay, Santa Cruz Island (Galápagos Islands) (McCann et al. 2015) (Fig. 1).

On the Pacific coast of Mexico, there are records of $A$. verticillata (as Z verticillatum and Z. pellucidum) from 3 northern states: Baja California Sur (Soule 1963, Brusca and Thomson 1977, Whitmore et al. 2005, MedinaRosas and Tovar-Hernández 2012), Sonora (MedinaRosas and Tovar-Hernández 2012), and Sinaloa (Soule 1963, Álvarez-León and Banta 1984, Medina-Rosas and Tovar-Hernández 2012) (Fig. 1A). Considering these, Okolodkov et al. (2007) and Medina-Rosas and TovarHernández (2012) categorized the species as exotic with invasive potential for the Mexican Pacific, as it has been recognized in other countries worldwide (e.g. Australia, Brazil, India, Lebanon, New Zealand, and the USA; Gordon and Mawatari 1992, Tilbrook 2012, Harmelin et al. 2016, Jebakumar et al. 2017, Fofonoff et al. 2018, Miranda et al. 2018).

We report for the first time the occurrence of $A$. verticillata in Oaxaca, extending the distribution of this species to the southern Mexican Pacific. We also discuss its introduction to Oaxaca.

\section{Methods}

Amathia verticillata was detected at 3 locations along the coast of Oaxaca, southern Mexico, between 2014 and 2018 (Fig. 1B). In Puerto Ángel Bay and Santa Cruz Bay, colonies of the bryozoan were photographed in situ, measured (total length), and collected by hand while snorkeling. On February 2018, exploration of an additional location (La Blanca Island) by SCUBA diving revealed the presence of several colonies of the species, which were recorded by photographs.

Collected colonies were cleaned and photographed alive using a Canon PowerShot SX60 HS digital camera mounted on a Zeiss SteREO Discovery.V8 stereomicroscope. Zooids (length and width) were measured using the software ImageJ 1.52a (Rasband 1997-2012). Specimens were fixed in approximately $4 \%$ formalin and preserved in $70 \%$ alcohol, or fixed and preserved in $96 \%$ alcohol.

The materials examined were deposited at the
Bryozoa section, part of the Scientific Collection of the Laboratorio de Sistemática de Invertebrados Marinos (LABSIM) (OAX-CC-249-11), Puerto Ángel, Oaxaca, Mexico. The species was identified based on descriptions of Amathia verticillata by Banta (1980), Winston (1984), Tovar-Hernández et al. (2012), and Vieira et al. (2014).

\section{Results}

Materials examined. Mexico, Oaxaca. Location 1: Puerto Ángel Bay $\left(15^{\circ} 39^{\prime} 55^{\prime \prime} \mathrm{N}, 096^{\circ} 29^{\prime} 28^{\prime \prime} \mathrm{W}\right)$, coll. Christopher Cruz-Gómez, April 2015 (1 colony on pier pilings, $1 \mathrm{~m}$, UMAR-BRYO-001). Location 2: Santa Cruz Bay $\left(15^{\circ} 45^{\prime} 07^{\prime \prime}\right.$ N, 096 07'52" W), coll. J. Pablo Sánchez-Ovando, November 2015 (1 colony on rocks, $1 \mathrm{~m}$, UMAR-BRYO-002); coll. Christopher CruzGómez, November 2018 (1 colony on rocks, $1.5 \mathrm{~m}$, UMAR-BRYO-003-OH).

Other observations. Mexico, Oaxaca. Location 1:

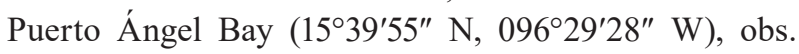
Christopher Cruz-Gómez and Karla J. Humara-Gil, December 2014; obs. Christopher Cruz-Gómez and J. Pablo Sánchez-Ovando, November 2016; obs. Christopher Cruz-Gómez and Karla J. Humara-Gil, December 2017; obs. Christopher Cruz-Gómez, February 2018; obs. Christopher Cruz-Gómez and Yessica Chávez-López, April 2018. Location 2: Santa Cruz Bay (15²5'07" N, 096 07'52" W), obs. Christopher Cruz-Gómez and Karla J. Humara-Gil, November 2017; obs. Christopher CruzGómez and Yessica Chávez-López, April 2018. Loca-

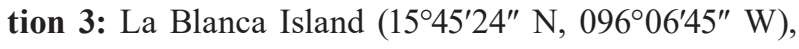
obs. Christopher Cruz-Gómez, February 2018.

Amathia verticillata was found from 2014 to 2018 at Puerto Ángel Bay, and in 2015, 2017, and 2018 at Santa Cruz Bay (Fig. 2A, B). Colonies from Puerto Ángel Bay were either brownish or translucent, arranged in small clumps (20-72 cm long) and, occasionally, in large mats (up to $3 \mathrm{~m}$ long) (Fig. 2D). At this location, colonies were found attached to pier pilings at depths of 1.2-4 m. Specimens from Santa Cruz Bay were brownish and bushlike (up to $80 \mathrm{~cm}$ long) (Fig. 2E) and were found attached to rocks near the cruise ship port at depths of 1-2 m.

The exploration of La Blanca Island (February 2018) revealed the presence of brownish colonies of $A$. verticillata arranged in small clumps (Figs 2C, F). Colonies were found attached to rocks between 8 and $16 \mathrm{~m}$ deep.

Examination of the colonies showed that $A$. verticillata provided a suitable substrate for marine invertebrates, such as polychaetes (Polyophtalmus cf. pictus, as well as species of Paleanotus, Nereis, Euthalenessa, Dorvilleidae, Polynoidae, and Terebellidae), brittle stars [Ophiactis simplex (Le Conte, 1851), Ophiocoma aethiops Lütken, 1859, Ophiothrix (Ophiothrix) spiculata Le Conte, 1851], anthozoids (Exaiptasia sp.), hydroids [Tridentata turbinata (Lamouroux, 1816) and Clytia sp.], other bryozoans (Amathia sp.), gastropods [Stylocheilus 

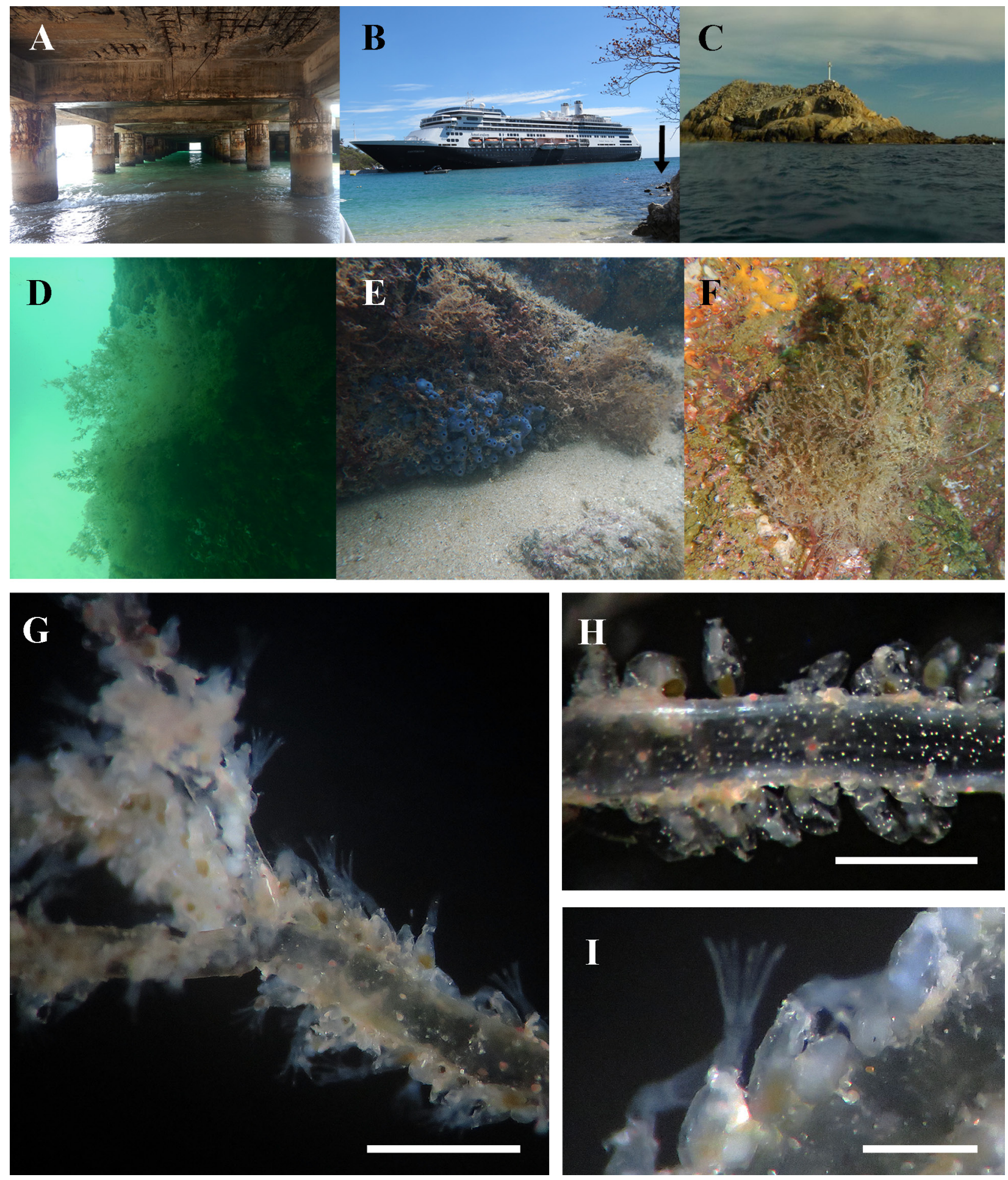

Figure 2. Amathia verticillata in Oaxaca. New records: A. Port of Puerto Ángel. B. Santa Cruz Bay. The arrow indicates where the species was found. C. La Blanca Island. D. Colonies on a pier piling in Puerto Ángel Bay. E. Colony on rocks in Santa Cruz Bay. F. Colony on rocks in La Blanca Island. Morphology: G. Trifurcated branch of a colony. Scale bar $=2 \mathrm{~mm}$. H. Stolon with zooids. Scale bar $=1 \mathrm{~mm}$. I. Zooid with its tentacle crown expanded. Scale bar $=0.5 \mathrm{~mm}$.

striatus (Quoy \& Gaimard, 1832)], isopods, amphipods, decapods, and pycnogonids.

Identification. Colonies of $A$. verticillata present a thick, translucent stolon showing a trifurcated branching pattern (Fig. 2G). Living colonies exhibit white pigment spots on the zooidal and stolon surfaces (Fig. 2H); these are indistinguishable in specimens stored in formalin and alcohol. Zooids are sac-shaped (about 0.57 mm long, $0.22 \mathrm{~mm}$ wide; $n=10)$ and arranged in clusters on both sides of the stolon (Fig. 2G, H). Polypides have 8 campanulate tentacles (Fig. 2I).

The morphology of the examined colonies agrees with the descriptions of $A$. verticillata provided by Banta (1980) from northern Mexico, Winston (1984) from Belize, and Vieira et al. (2014) from Brazil. Regarding zooidal measurements, Tovar-Hernández et al. (2012) 
included a brief diagnosis of $A$. verticillata and established that the length of its zooids varies from 0.4 to $0.6 \mathrm{~mm}$; this was also observed in the material that we examined.

A feature of the species that is not often mentioned is the presence of white pigment spots on its surface; these pigment spots have only been figured by Vieira et al. (2014: figs 98-101). Other Amathia species with white pigment spots are A. brasiliensis Busk, 1886, A. maxima (Winston, 1982), and A. evelinae (Vieira, Migotto $\&$ Winston, 2014). However, A. verticillata can be easily recognized based on: (1) its arrangement of zooids on both sides of the stolon, rather than forming spirals as in A. brasiliensis and (2) smaller (up to $0.6 \mathrm{~mm}$ ), ovoid zooids compared to the large (up to $1 \mathrm{~mm}$ ), tubular ones of $A$. maxima and $A$. evelinae.

\section{Discussion}

Introduction of Amathia verticillata to the coast of Oaxaca, Mexico. Two main anthropogenic dispersal vectors are responsible for the introduction of $A$. verticillata worldwide: rafting on drifting material and shipping, either by hull-fouling or in ballast water (Farrapeira 2011, Minchin 2012, Marchini et al. 2015, McCann et al. 2015, Harmelin et al. 2016, Minchin et al. 2016, Miranda et al. 2018). On the coast of Oaxaca, rafting has not been observed.

Some facts indicate shipping as a dispersal vector of $A$. verticillata at the studied locations: the species was found directly (on pier pilings) or partially (on rocks near the cruise ship port) associated with ports, and the 3 locations documented here are influenced by marine traffic. Puerto Ángel Bay is constantly receiving local vessels which are based out of this port. Some recreational vessels also arrive at this bay from Huatulco, the neighboring municipality to which Santa Cruz Bay and La Blanca Island belong. Huatulco has an important cruise ship port at Santa Cruz Bay and a marina at Chahué Bay; both facilities receive numerous national and international vessels (FONATUR Operadora Portuaria 2017). Compared to the other locations, La Blanca Island has less marine traffic; however, it also receives some recreational vessels.

Also of note is that the cruise ship port of Santa Cruz is part of the transcanal route, going from the east to the west coast of the USA across the Isthmus of Panama (FONATUR Operadora Portuaria 2017). Along this route this species has already been recorded from Panama, Los Angeles, San Diego, and San Francisco (McCann et al. 2015, Fofonoff et al. 2018), which could represent dispersal centers.

For other exotic species recorded from the coast of Oaxaca, such as algae, polychaetes and sponges, shipping has also been suggested as one of the most likely mechanisms for their introduction (Okolodkov et al. 2007, Aguilar-Rosas et al. 2014, Bastida-Zavala et al. 2014, 2016).
It is uncertain whether $A$. verticillata was already established in the coast of Oaxaca before it was first noticed in 2014. Bryozoans are not well known from this region (Bastida-Zavala et al. 2013), so the presence of the species could be easily unnoticed. Although this species was first recorded from Puerto Ángel Bay, this bay might not be the first location in which $A$. verticillata was introduced. No surveys were carried out at Santa Cruz Bay or La Blanca in 2014, so it is impossible to know if the bryozoan was already established there. The absence of records from Santa Cruz Bay in 2016 is also due to a lack of surveys.

The discovery of $A$. verticillata in Oaxaca brings up some questions. Where did it come from? Does it occur at more locations along the coast of Oaxaca or more generally in the Mexican Pacific? Is it negatively affecting the local fauna and flora? These and other questions can only be answered using ecological and molecular approaches in the future.

Factors influencing the distribution of Amathia verticillata worldwide. The cosmopolitan, or more properly termed, pantropical distribution pattern exhibited by $A$. verticillata has been explained as a result of dispersal (e.g. Marchini et al. 2015, McCann et al. 2015). This process assumes that the species was able to (1) reach new areas, (2) survive potentially unfavorable oceanographic conditions during its transit and at the new areas, and (3) establish viable populations (Lomolino et al. 2006).

Concerning the first point, several authors (Farrapeira 2011, Minchin 2012, Marchini et al. 2015, McCann et al. 2015, Harmelin et al. 2016, Minchin et al. 2016) agree that the main vector of dispersal of $A$. verticillata is shipping. This can occur as a result of vessel hull-fouling or transport in ballast water of fragments of colonies that are capable of reattaching to new substrata (Robinson 2004, Minchin 2012, Marchini et al. 2015, McCann et al. 2015). Larval transport via ballast water is unlikely, as the species has short-lived non-feeding larvae, which cannot survive long journeys (Minchin 2012, Marchini et al. 2015, McCann et al. 2015, Miranda et al. 2018). Harmelin et al. (2016) suggested that larvae in ballast water could settle on ballast tanks and develop new colonies; however, there is no evidence of this so far. Other than shipping, A. verticillata could be transported by rafting on natural or artificial substrata (Marchini et al. 2015, Harmelin et al. 2016). However, to date it has only been found associated with artificial materials such as fishing cages and ropes (Marchini et al. 2015, Minchin et al. 2016).

Still, transporting itself does not guarantee that a species' dispersal will be successful. As was mentioned, species must be capable of withstanding the adverse conditions during transit and at the new settlement area. It seems as if $A$. verticillata has achieved this. So what has allowed the species to survive in so many different places worldwide? The answer is its capacity of living under variable conditions (=euryoeciousness), 
in multiple habitats (=eurytopicity) (Vieira et al. 2014, Marchini et al. 2015).

According to Minchin et al. (2016), A. verticillata is euryhaline and presents greater activity in waters with salinities of 20-30 psu, but endures salinities up to 56 psu. Additionally, while $A$. verticillata develops best in warmer waters (over $20^{\circ} \mathrm{C}$ ), it tolerates moderate variations in temperature (Winston 1995, Marchini et al. 2015).

This bryozoan is also considered a generalist species, able to colonize various types of habitats. Amathia verticillata occurs in turbid waters such as ports, as well as clear-water habitats such as eel-grass beds and coastal lagoons (Winston 1995, Ferrario et al. 2014, Minchin et al. 2016).

Regarding the capacity of living in multiple habitats, the broad, robust stolon of colonies of $A$. verticillata makes this species well adapted to hull-fouling (Marchini et al. 2015). Compared to other non-calcareous fouling organisms (e.g. benthic hydroids) at the locations in this study, A. verticillata was more resistant to detachment from the substrata.

The final characteristic that could be an advantage for the dispersal and settlement of Amathia verticillata is the production of secondary metabolites. This species produces bromo-alkaloids, which prevent the settlement of other fouling organisms (Winston 1995, Santos et al. 2017). Some authors (Winston 1995, Marchini et al. 2015) establish that these compounds might even discourage predators or provide protection against viral or bacterial diseases. Conversely, Santos et al. (2017) concluded that bromo-alkaloids do not have a significant role in the chemical defense of $A$. verticillata. To understand the role that bromo-alkaloids have as defense, if any, more investigation is needed.

Final considerations. As stated by Medina-Rosas and Tovar-Hernández (2012) and reaffirmed by McCann et al. (2015), until recently no records of $A$. verticillata were known from the Pacific coasts of tropical Mexico and Central America. Our study presents the first records of the species within these regions. Furthermore, A. verticillata is the second bryozoan ever recorded from the state of Oaxaca, preceded only by Cryptosula pallasiana (Moll, 1803) (Bastida-Zavala et al. 2013).

Although $A$. verticillata can be recognized using morphological features alone, as done in our study, molecular tools can provide greater knowledge about the origin and dispersal of this bryozoan. This is important because it is still unclear if $A$. verticillata is a widespread species or a complex of cryptic species (Nascimento 2015, Waeschenbach et al. 2015). To date, only few studies (Nascimento 2015, Waeschenbach et al. 2015, Miralles et al. 2016, Santos et al. 2017) have confirmed the identity of the bryozoan from 6 countries (Australia, Brazil, Italy, Mexico, Spain, and the USA) using molecular analyses. Applying this type of approach to Mexican specimens will not only allow a more accurate identification, but also give evidence on the introduction and dispersal of this species in the country.

Finally, we highlight the importance of monitoring this non-native species in Mexico, as its introduction might have significant implications (see Introduction; Amat and Tempera 2009, Marchini et al. 2015, McCann et al. 2015). The first step would be to identify where the species is already established. Until now, $A$. verticillata has a disjunct distribution in the country (Fig. 1A, B) but the lack of records from other sites in Mexico might be due to the reduced number of studies focused on these organisms rather than the species not being able to establish viable populations (Medina-Rosas and TovarHernández 2012).

\section{Acknowledgements}

We thank Leandro Vieira (Universidade Federal de Pernambuco [UFPE], Recife) for confirming the identification of Amathia verticillata and for his helpful comments on this paper. Thanks are also extended to María A. Tovar-Hernández (Universidad Autónoma de Nuevo León, Nuevo León) for providing literature and for her comments about the species' distribution, and Yasmín González-Reyes, Walter Alonso and Andrés Jiménez-Solar (Universidad del Mar [UMAR], Puerto Ángel) for sharing some of the photographs (Fig. 3B, C, F). We also thank Yessica Chávez-López and J. Pablo Sánchez-Ovando (LABSIM-UMAR, Puerto Ángel) for their assistance during fieldwork, and Uriel Cortés-Jiménez (UMAR, Puerto Ángel) for helping us to identify the anthozoans. We are grateful to Ana C.S. Almeida (UFPE, Recife), Rebeca Granja-Fernández (Universidad Autónoma Metropolitana-Iztapalapa, Mexico City), Derek Joe Brockett (UMAR, Puerto Ángel) and an anonymous reviewer for their valuable comments to improve the original manuscript. We thank Rafael B. de Moura (Universidade Federal do Rio de Janeiro, Rio de Janeiro) and Robert G. Forsyth (New Brunswick Museum, Saint John) for guiding the manuscript through the editorial process. Finally, we wish to thank Samantha KaramMartínez (UMAR, Puerto Ángel), Socorro García-Madrigal and Rolando Bastida-Zavala (LABSIM-UMAR, Puerto Ángel) for motivating us to start the projects which resulted in this manuscript.

\section{Authors' Contributions}

KJHG and CCG carried out the surveys and identified the species; KJHG and CCG identified the invertebrates associated with the species; KJHG led the writing; KJHG and CCG took the photographs and measured the specimens; KJHG and CCG prepared the figures.

\section{References}

Aguilar-Rosas LE, Pedroche FF, Zertuche-González JA (2014) Algas marinas no nativas en la costa del Pacífico mexicano. In: Men- 
doza R, Koleff P (Eds) Especies acuáticas invasoras en México. Comisión Nacional para el Conocimiento y Uso de la Biodiversidad, Ciudad de México, 317-336.

Álvarez-León R, Banta WC (1984) Briozoarios de tres esteros adyacentes a Mazatlán, Costa noroeste de México. Studies on Neotropical Fauna and Environment 19 (4): 209-218.

Amat JN, Tempera F (2009) Zoobotryon verticillatum Della Chiaje, 1822 (Bryozoa), a new occurance in the archipelago of the Azores (North-Eastern Atlantic). Marine Pollution Bulletin 58: 761-764. https://doi.org/10.1016/j.marpolbul.2009.02.019

Banta WC (1980) Bryozoa (moss animals). In: Brusca RC (Ed.) Common intertidal invertebrates of the Gulf of California. The University of Arizona Press, Tucson, 356-396.

Bastida-Zavala JR, León-González JA de, Carballo JLC, MorenoDávila B (2014) Invertebrados bénticos exóticos: Esponjas, poliquetos y ascidias. In: Mendoza R, Koleff P (Eds) Especies acuáticas invasoras en México. Comisión Nacional para el Conocimiento y Uso de la Biodiversidad, Ciudad de México, 317-336.

Bastida-Zavala JR, Buelna ASR, León-González JA de, Camacho-Cruz KA, Carmona I (2016) New records of sabellids and serpulids (Polychaeta: Sabellidae, Serpulidae) from the Tropical Eastern Pacific. Zootaxa 4184 (3): 401-457. https://doi. org/10.11646/zootaxa.4184.3.1

Bastida-Zavala JR, García-Madrigal MS, Rosas-Alquicira EF, LópezPérez RA, Benítez-Villalobos F, Meraz-Hernando JF, TorresHuerta AM, Montoya-Márquez A, Barrientos-Luján NA (2013) Marine and coastal biodiversity of Oaxaca, Mexico. Check List 9 (2): 329-390. https://doi.org/10.15560/9.2.329

Brusca RC, Thomson DA (1977) Pulmo Reef: The only "coral reef” in the Gulf of California. Ciencias Marinas 1 (3): 37-53.

Cohen AN, Carlton JT (1995) Non-indigenous aquatic species in a United States estuary: a case of study of the biological invasions of San Francisco Bay and Delta. U.S. Fish and Wildlife Service, National Sea Grant College Program, Washington D.C., 247 pp.

Delle Chiaje S (1822-1828) Memorie sulla storia e notomia degli animali senza vertebre del regno di Napoli. Societé Tipográfica, Napoli, xx + 232 pp. (1828), 109 pls. (1822). https://doi org/10.5962/bhl.title.10021

Ehrenberg CG (1831) Symbolae physicae, seu icones et descriptions corporum naturalium novorum aut minus cognitorum quae ex itineribus per Libyam, Aegyptum, Nubiam, Dongalam, Syriam, Arabiam et Habessinian à P.C. Hemprich et C.G. Ehrenberg à studio annis 1820-25 redierunt à pars Zoologica. Vol 4. Animalia Evertebrata exlusis Insects. Berolini, Berlin, 126 pp.

Farrapeira CMR (2011) The introduction of the bryozoan Zoobotryon verticillatum (Della Chiaje, 1822) in northeast of Brazil: a cause for concern. Biological Invasions 13 (1): 13-16. https://doi. org/10.1007/s10530-010-9788-6

Ferrario J, Marchini A, Lodola A, Occhipinti Ambrogi A (2014) The pseudoindigenous bryozoan Zoobotryon verticillatum along the Mediterranean and European Atlantic coasts. Biologia Marina Mediterranea 21 (1): 117-118.

Fofonoff PW, Ruiz GM, Steves B, Simkanin C, Carlton JT (2018) National Exotic Marine and Estuarine Species Information System. http://invasions.si.edu/nemesis/. Accessed on: 2018-09-02.

FONATUR Operadora Portuaria (2017) Administración Portuaria Integral de Bahías de Huatulco. http://www.fonaturoperadora portuaria.gob.mx/micrositios/API/Huatulco/QuienesSomosH. asp/. Accessed on: 2017-10-27.

Galil BS, Gevili R (2014) Zoobotryon verticillatum (Bryozoa: Ctenostomatida: Vesiculariidae), a new occurrence on the Mediterranean coast of Israel. Marine Biodiversity Records 7: e17. https:// doi.org/10.1017/S1755267214000086

Gordon DP, Mawatari SF (1992) Atlas of marine-fouling Bryozoa of New Zealand ports and harbours. Miscellaneous Publications, New Zealand Oceanographic Institute 107: 1-52.

Harmelin JG, Bitar G, Zibrowius H (2016) High xenodiversity versus low native diversity in the south-eastern Mediterranean: bryo- zoans from the coastal zone of Lebanon. Mediterranean Marine Science 17 (2): 417-439. https://doi.org/10.12681/mms.1429

Jebakumar JPP, Nandhagopal G, RajanBabu B, Ragumaran S, Ravichandran V, Marchini A, Minchin D (2017) The bryozoan Amathia verticillata (delle Chiaje, 1822) fouling harbours of the southeast coast of India: re-evaluating its status. BioInvasions Records 6 (3): 211-216. https://doi.org/10.3391/bir.2017.6.3.05

Lomolino MV, Riddle BR, Brown JH (2006) Biogeography. Sinauer Associates, Sunderland, Massachusetts, $752 \mathrm{pp}$.

Marchini A, Ferrario J, Minchin D (2015) Marinas may act as hubs for the spread of the pseudo-indigenous bryozoan Amathia verticillata (Delle Chiaje, 1822) and its associates. Scientia Marina 79 (3): 355-365. https://doi.org/10.3989/scimar.04238.03A

McCann L, Keith I, Carlton JT, Ruiz GM, Dawson TP, Collins K (2015) First record of the non-native bryozoan Amathia (=Zoobotryon) verticillata (delle Chiaje, 1822) (Ctenostomata) in the Galápagos Islands. BioInvasions Records 4 (4): 255-260. https://doi. org/10.3391/bir.2015.4.4.04

Medina-Rosas P, Tovar-Hernández AM (2012) Bryozoa, Cnidaria, Kamptozoa. In: Low-Pheng AM, Peters-Recagno EM (Eds) Invertebrados marinos exóticos en el Pacífico mexicano. Geomare, A.C., INE-SEMARNAT, México, 107-128.

Minchin D (2012) Rapid assessment of the bryozoan, Zoobotryon verticillatum (Delle Chiaje, 1822) in marinas, Canary Islands. Marine Pollution Bulletin 64: 2146-2150. https://doi.org/10.1016/j.marpolbul. 2012.07.041

Minchin D, Liu T-K, Cheng M (2016) First record of bryozoan Amathia (=Zoobotryon) verticillata (Bryozoa: Vesiculariidae) from Taiwan. Pacific Science 70 (4): 509-517. https://doi.org/10.2984/70.4.9

Miralles L, Ardura A, Arias A, Borrell YJ, Clusa L, Dopico E, Hernandez de Rojas A, Lopez B, Muñoz-Colmenero M, Roca A, Valiente AG, Zaiko A, Garcia-Vazquez E (2016) Barcodes of marine invertebrates from north Iberian ports: native diversity and resistance to biological invasions. Marine Pollution Bulletin 112 (1-2): 183-188. https://doi.org/10.1016/j.marpolbul.2016.08.022

Miranda AA, Almeida ACS, Vieira LM (2018) Non-native marine bryozoans (Bryozoa: Gymnolaemata) in Brazilian waters: assessment, dispersal and impacts. Marine Pollution Bulletin 130 184-191. https://doi.org/10.1016/j.marpolbul.2018.03.023

Nascimento KB (2015) Investigation of the distribution pattern of the cosmopolitan bryozoan Zoobotryon verticillatum (Ctenostomata, Vesiculariidae), using molecular data. Master dissertation, Universidade de São Paulo, São Paulo, 97 pp.

Okolodkov YB, Bastida-Zavala R, Ibáñez AL, Chapman JW, SuárezMorales E, Pedroche F, Gutiérrez-Mendieta FJ (2007) Especies acuáticas no indígenas en México. Ciencia y Mar 11 (32): 29-67.

Osburn RC (1953) Bryozoa of the Pacific coast of America, part 3, Cyclostomata, Ctenostomata, Entoprocta and Addenda. Allan Hancock Pacific Expeditions 14 (3): 613-841. https://doi.org/10.5962/ blh.title. 6542

Rasband WS (1997-2012) ImageJ, US National Institutes of Health, Bethesda, Maryland, USA. http://imagej.nih.gov/ij/

Robertson A (1921) Report on a collection of Bryozoa from the Bay of Bengal and other eastern seas. Records of the Indian Museum 22: 33-65. https://doi.org/10.5962/bhl.part.1465

Santos LAH dos, Clavico EEG, Parra LLL, Berlinck RGS, Ferreira AG, Paul VJ, Pereira RC (2017) Evaluation of chemical defense and chemical diversity in the exotic bryozoan Amathia verticillata. Journal of the Brazilian Chemical Society 28 (3): 435-442. https://doi.org/10.21577/0103-5053.20160257

Soule JD (1963) Results of the Puritan-American Museum of Natura History Expedition to Western Mexico 18. Cyclostomata, Ctenostomata (Ectoprocta), and Entoprocta of the Gulf of California. American Museum Novitates 2144: 1-34.

Tilbrook KJ (2012) Bryozoa, Cheilostomata: first records of two invasive species in Australia and the northerly range extension for a third. Check List 8 (1): 181-183. https://doi.org/10.15560/8.1.181 
Tovar-Hernández MA, Villalobos-Guerrero TF, Yáñez-Rivera B, Aguilar-Camacho JM, Ramírez-Santana ID (2012) Guía de invertebrados acuáticos exóticos en Sinaloa. Geomare A.C., USFWS, INE-SEMARNAT, Mazatlán, México, 41 pp.

Vieira LM, Migotto AE, Winston JE (2014) Ctenostomatous Bryozoa from São Paulo, Brazil, with descriptions of twelve new species. Zootaxa 3889 (2): 485-524. https://doi.org/10.11646/ zootaxa.3889.4.2

Waeschenbach A, Vieira LM, Reverter-Gil O, Souto-Derungs J, Nascimento KB, Fehlauer-Ale KH (2015) A phylogeny of Vesiculariidae (Bryozoa, Ctenostomata) supports synonymization of three genera and reveals possible cryptic diversity. Zoologica Scripta 44 (6): 667-683. https://doi.org/10.1111/zsc.12130

Whitmore RC, Brusca RC, León de la Luz JL, González-Zamoran
P, Mendoza-Salgado R, Amador-Silva ES, Holguin G, GalvánMagaña F, Hastings PA, Cartron J-LE, Felger RS, Seminoff JA, McIvor CC (2005) The ecological importance of mangroves in Baja California Sur: Conservation implications for an endangered ecosystem. In: Cartron J-LE, Ceballos G, Felger RS (Eds) Biodiversity, ecosystems, and conservation in northern Mexico. Oxford Press, New York, 298-333.

Williams SL (2007) Introduced species in seagrass ecosystems: status and concerns. Journal of Experimental Marine Biology and Ecology 350: 89-110. https://doi.org/10.1016/j.jembe.2007.05.032

Winston JE (1984) Shallow-water bryozoans of Carrie Bow Cay, Belize. American Museum Novitates 2799: 1-38.

Winston JE (1995) Ectoproct diversity of the Indian River coastal lagoon. Bulletin of Marine Science 57 (1): 84-93. 